\title{
KARAKTERISTIK HIDRODINAMIKA DI PERAIRAN TELUK AMBON UNTUK MENDUKUNG WISATA SELAM
}

\section{HYDRODYNAMIC CHARACTERISTICS IN AMBON BAY WATERS TO SUPPORT MARINE DIVING TOURISM}

\author{
Koko Ondara*), Ulung Jantama Wisha, Guntur Adhi Rahmawan
}

Research Institute for Coastal Resources and Vulnerability, Ministry of Marine Affairs and Fisheries. Jl. Raya Padang-Painan KM. 16, Bungus, Padang - Sumatera Barat, Indonesia 25245 ${ }^{*}$ Corresponding author e-mail: kornkoko@yahoo.com

Submitted: 24 Februari 2017 / Revised: 26 April 2017 / Accepted: 26 April 2017

http://doi.org/10.21107/jk.v10i1.2170

\begin{abstract}
Ambon Bay is divided by two thresholds, namely Teluk Ambon Dalam and Teluk Ambon Luar. Ambon bay is rich in marine potential both the unique of fisheries and coral reefs as well as the objects such as shipwreck that could be developed as a maritime tourism potential. The aim of this study is to investigate the characteristics of waves and tides in the waters of Ambon Bay (inner and outer of Ambon Bay) by using numerical simulation. The method is using purposive quantitative, the primary data are consisted of Bathymetry, Tide, and wind, while the secondary data is consisted of tide forecasting by MIKE 21, Flow Model FM Hydrodynamic Module is used to simulate tidal and current patterns that are used as input in the wave spectral module MIKE 21. From the data obtained, the tidal type of Ambon Bay waters is mixed tide prevailing semidiurnal based on Formzahl value 0.0602 which obtained from the diurnal and semidiurnal major tide component calculation, Mean Sea Level is $124.76 \mathrm{~cm}$, Zo is $148.72 \mathrm{~cm}$ and the value of Chart Datum is -23.96 $\mathrm{cm}$. Current speed ranged from 0009-1463 $\mathrm{m} / \mathrm{s}$ while the significant wave height ranged from 0 $0.00279 \mathrm{~m}$. Ambon Bay hydrodynamic conditions are calm and not too volatile, fortunately supportive in marine tourism activities of SS.Aquila site.
\end{abstract}

Keywords: Currents, Hydrodynamics, SS. Aquila, Tides

\section{ABSTRAK}

Teluk Ambon terbagi oleh dua ambang yaitu Teluk Ambon Dalam dan Teluk Ambon Luar. Teluk Ambon kaya akan potensi baharinya baik dari keunikan ikan, terumbu karang maupun bendabenda seperti kapal tenggelam yang bisa dikembangkan potensinya sebagai wisata bahari. Penelitian kali ini bertujuan untuk mengetahui karakteristik gelombang dan pasang surut yang ada di perairan Teluk Ambon dengan menggunakan simulasi numerik.Metode yang digunakan adalah metode purposive kuantitatif, data primer terdiri dari batimetri, pasang surut dan angin, sedangkan data sekunder terdiri dari data peramalan pasang surut menggunakan MIKE 21, Flow Model FM Hydrodynamic Module digunakan untuk mensimulasikan pola pasang surut dan arus yang kemudian dijadikan sebagai input dalam modul spectral wave MIKE 21. Dari data pengolahan pasut didapatkan tipe pasut Teluk Ambon adalah condong harian ganda berdasarkan nilai bilangan Formzahl yang diperoleh yaitu sebesar 0.602 dari komponen pasut tunggal utama dan ganda utama, Mean Sea Level sebesar $124.76 \mathrm{~cm}$, Zo $148.72 \mathrm{~cm}$ dan nilai Chart Datum -23.96 cm. Kecepatan arus rata-rata 0.009-1.463 m/s sedangkan tinggi gelombang signifikan 0-0.00279 m. Kondisi hidrodinamika Teluk Ambon sangat mendukung dalam kegiatan wisata bahari minat khusus salah satunya adalah SS Aquila.

Kata Kunci: Hydrodinamika, SS.Aquila, Gelombang, Arus, Pasang Surut 


\section{PENDAHULUAN}

Teluk Ambon merupakan perairan pesisir yang berada di Pulau Ambon dan terbagi oleh dua ambang yang sempit yaitu Teluk Ambon Dalam dan Teluk Ambon Luar. Pulau Ambon sendiri berada diantara dua buah laut dalam yaitu Laut Banda dan Laut Seram. Teluk Ambon memiliki garis pantai sepanjang 107,2 $\mathrm{km}$ dan Laut Banda merukan salah satu wilayah pengelolaan perikanan (WPP) di Maluku. Di perairan Maluku, diestimasi potensi sumberdaya perikanan sebesar 2.627,5 juta ton per tahun (Kaihatu, 2010. Beberapa rentetan sejarah sangat melekat pada kota ini. Tak lepas dari itu tinggalantinggalan sejarah berupa banteng dan kapalkapal karam banyak ditemukan di dasar perairan laut Teluk Ambon.

Teluk Ambon kini mengalami degradasi fungsi akibat pencemaran dan sampah serta aktifitas manusia yang tidak terkendali (Pattipeilohy, 2014). Penurunan kualitas tersebut antara lain berkurangnya ekosistem mangrove (Suyadi, 2012), perubahan tata guna lahan pemukiman (Selanno et al., 20015) dan kerusakan daerah pesisir (Hiariey dan Baskoro, 2011). Dampak dari pemanfaatan sumberdaya yang tidak berkelanjutan tersebut tentu akan menghambat pengembangan potensi Teluk Ambon khususnya di bidang perikanan dan kelautan. Beberapa potensi dibidang perikanan dan kelautan yang bisa dikembangkan antara lain dibidang ekowisata (Pattipilohy, 2014), ikan baronang, perikanan laut dalam, mangrove, wisata selam, budidaya perikanan serta di bidang perindustrian dan perdagangan (Latuconsina et al., 2012).Tujuan dari penelitian ini adalah untuk mengetahui keadaan pasang surut, gelombang laut, karakteristik angin serta kondisi penyelaman di perairan teluk ambon untuk menunjang pengembangan wisata minat khusus di perairan tersebut.

\section{MATERI DAN METODE}

Kegiatan penelitian dilakukan pada bulan 10 Mei sampai 2 Juli 2016 berlokasi di Teluk Ambon. Pengumpulan data primer yang dilakukan adalah pengumpulan data pasang surut, batimetri, kecepatan dan arah arus dan suhu. Untuk data sekunder yang diperoleh adalah data cuaca 10 tahun (2005-2016) dari BMKG Bandara Pattimura, peta Dishidros, LPI dan RBI.

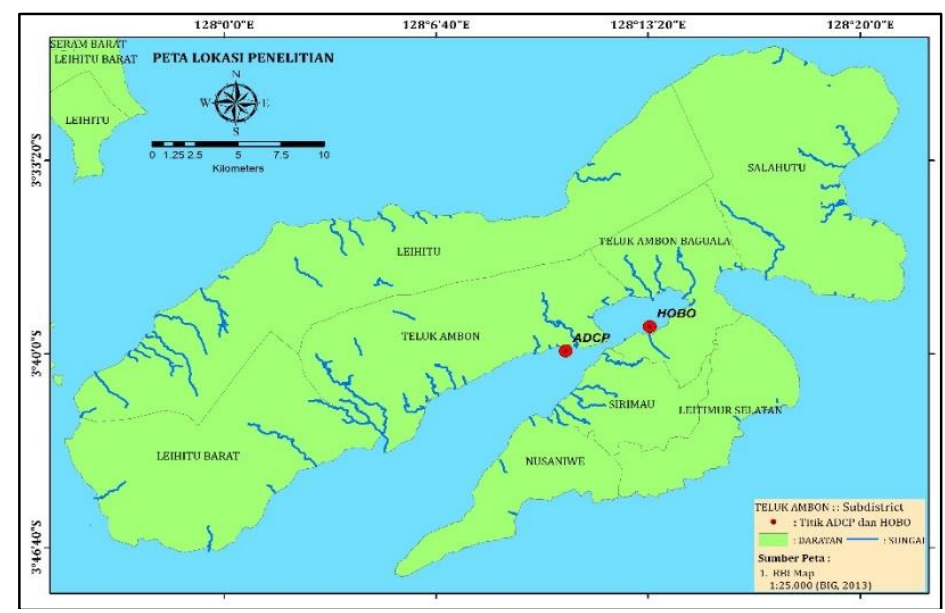

Gambar 1. Peta lokasi penelitian

Tujuan dari analisa pemodelan ini adalah untuk menganalisis gelombang di Perairan Teluk Ambon sehingga diketahui proses karakteristik, pola penjalaran, refraksi dan difraksi. Pengambilan data primer berupa data batimetri, pasang surut, kecepatan angin serta kecepatan dan arah arus. Pengukuran pasang surut menggunakan ADCP (Accoustic Doppler Current Profiler), karakteristik cuaca menggunakan AWS (Automatic Wheater Station) dan arus menggunakan HOBO. Data kedalaman perairan diukur menggunakan echosounder. Pengolahan data pasang surut dilakukan untuk memperoleh nilai konstanta pasang surut yang akan digunakan untuk mendapatkan nilai MSL, HHWL dan LLWL. Nilai-nilai tersebut diperoleh dari perhitungan 
berdasarkan komponen penting pasang surut berdasrakan analisa admiralty, sebagai berikut:

$M S L$ (muka air raut rerata) $=Z 0+1,1(M 2+S 2)$

$H H W L$ (muka air tinggi tertinggi) $=Z 0+(M 2+S 2)+(O 1+K 1)$

$L L W L$ (muka air laut rendah terendah) $=Z \mathbf{O}$ $(\mathrm{M} 2+\mathrm{S} 2)-(\mathrm{O1}+\mathrm{K} 1)$

Data batimetri dikoreksi terhadap pasang surut untuk mendapatkan nilai muka air ratarata. Data kecepatan angin diolah untuk mendapatkan nilai tinggi dan periode gelombang. Data pasang surut, kecepatan angin serta tinggi dan periode gelombang digunakan sebagai data masukan untuk pemodelan hidrodinamika.

Flow Model FM Hydrodynamic Module digunakan untuk mensimulasikan pola pasang surut dan arus. Modul ini didasarkan pada solusi numerik persamaan perairan dangkal dua dimensi-kedalaman terintegrasi persamaan Navier-Stokes dengan persamaan dasar sebagai berikut:

$$
S=\frac{\partial u}{\partial x}+\frac{\partial v}{\partial y}+\frac{\partial w}{\partial z}
$$

Model ini terdiri atas persamaan kontinuitas dan momentum. Directional decoupled parametric formulation berdasarkan parameterisasi dari persamaan konservasi wave action. Parameterisasi dilakukan pada frekuensi dominan dengan menjadikan momen ke-nol dan momen ke-satu sebagai variabel yang bergantung pada variabel lain (Holthuijsen, 1989). Fully spectral formulation berdasarkan persamaan konservasi wave action seperti dijelaskan pada Komen et al. (1994) dan Young (1999), dimana frekuensi tiap arah dari spektrum wave action adalah variabel yang bergantung pada variabel lain. Diskritsasi persamaan pembangun dalam geographical dan ruang spektral menggunakan metode cellcentered finite volume. Pada domain geographical digunakan unstructrured mesh. Integrasi waktu dengan pendekatan langkah fractional dengan metode multi-sequence untuk perhitungan penjalaran wave action. Model ini juga digunakan untuk perhitungan transpor sedimen, yang sebagian besar ditentukan oleh kondisi gelombang dan gelombang yang dipengaruhi arus. Gelombang yang dipengaruhi arus dibangkitkan oleh perbedaan fluks momentum (radiation stress) yang muncul di surf zone.

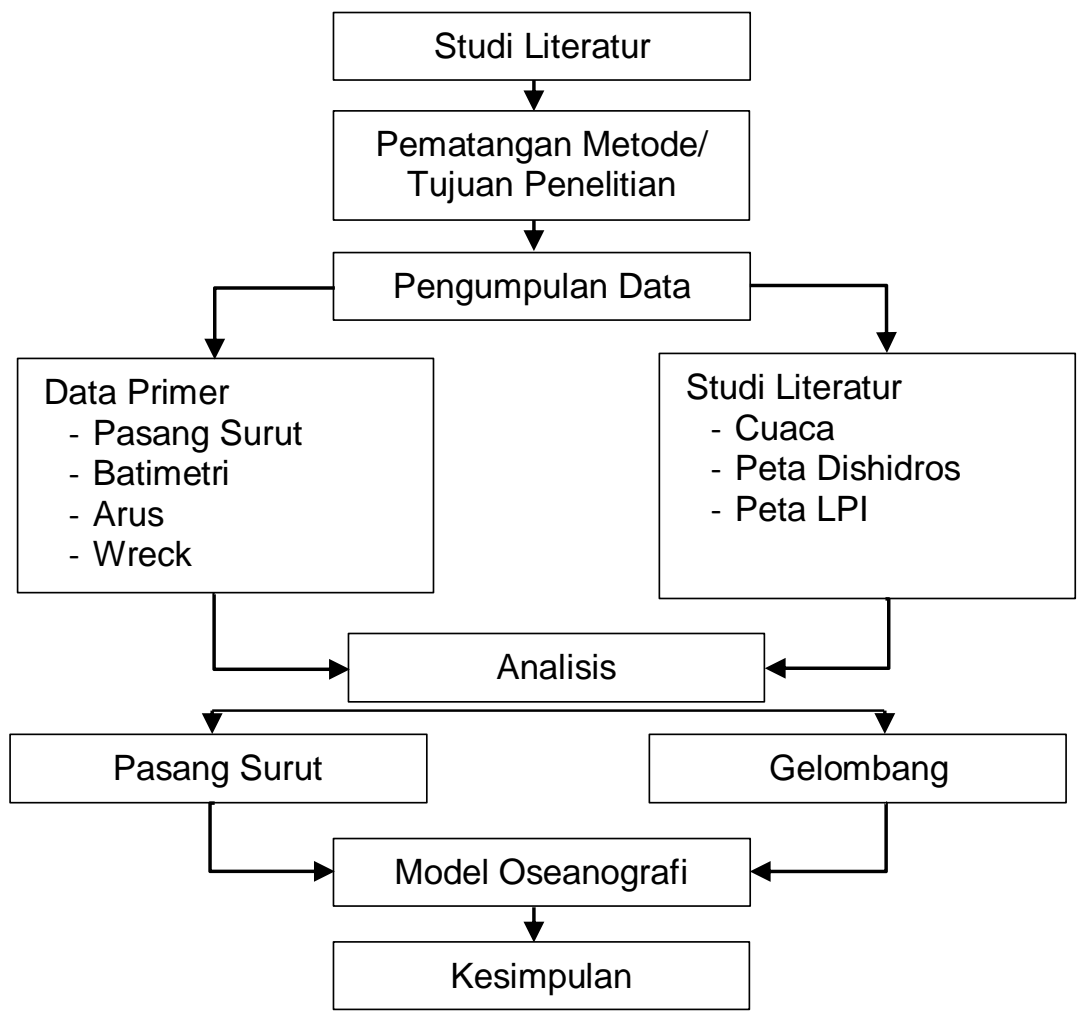

Gambar 2. Diagram alir penelitian 


\section{HASIL DAN PEMBAHASAN}

Data pasang surut yang diperoleh dari pengukuran langsung pada tanggal $19 \mathrm{Mei}$ sampai dengan 3 Juni 2016 diolah sehingga mendapatkan pasang surut maksimum dan minimum. Untuk memperoleh data pasang surut yang terjadi pada tahun 2016, digunakan pemodelan MIKE21 dengan modul Tidal Prediction of Heights. Hasil pemodelan dan hasil lapangan diverifikasi untuk mendapatkan keakuratan hasil pasang surut tahunan yang akan digunakan.
Data pasang surut pada gambar 3 menunjukkan fluktuasi muka air laut serta dapat digunakan untuk menentukan elevasi muka air laut. Tipe pasut di perairan Teluk Ambon adalah pasut campuran condong harian ganda dengan nilai $F=0.602$, hal tersebut terlihat dari besarnya nilai amplitudo pada konstanta pasut campuran $\mathrm{M}_{2}$ sebesar 55.16 dengan beda fasa paling tinggi sebesar 207.24. Mean Sea Level (muka laut ratarata) perairan Teluk Ambon sebesar 124.76 $\mathrm{cm}$, Zo sebesar $148.72 \mathrm{~cm}$ dan nilai Chart Datum -23.96 cm.

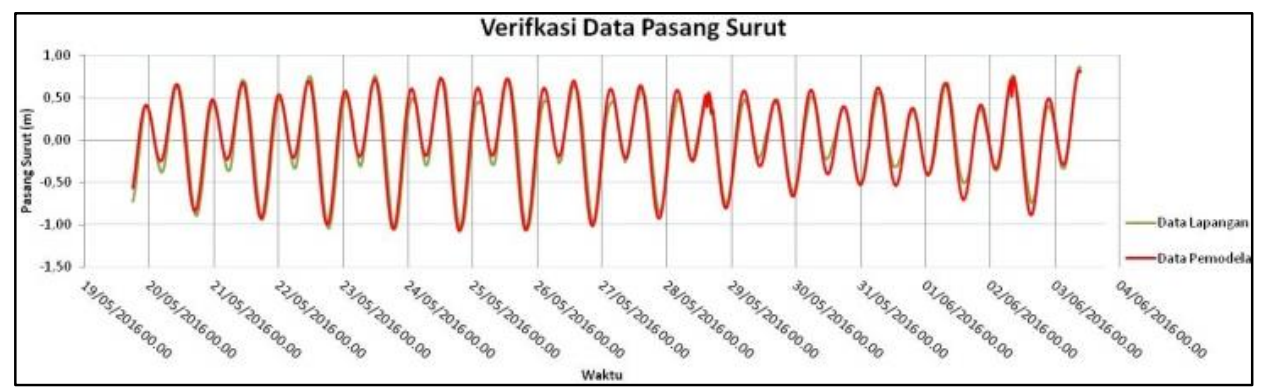

Gambar 3. Verifikasi data pasang surut pemodelan dan lapangan

Pengukuran batimetri menggunakan echosounder dengan lajur pengukuran dibuat dalam 2 interval yaitu $50 \mathrm{~m}$ dan $500 \mathrm{~m}$.Dari hasil pengukuran batimetri terlihat kedalaman dasar laut di Perairan Teluk Ambon bagian luar dan Teluk Ambon bagian dalam memiliki karakteristik yang berbeda.

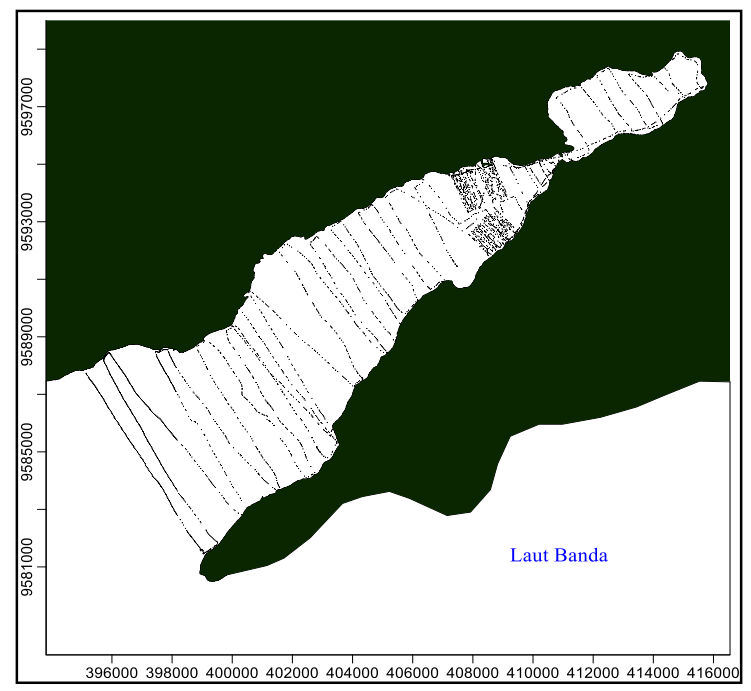

Gambar 4. Jalur pengeruman batimetri

Pada teluk Ambon bagian luar sangat curam dengan interval 0-500 $\mathrm{m}$, hal ini dapat dilihat dari kerapatan tiap-tiap interval kontur yang jaraknya tidak terlalu jauh antara satu dengan yang lainnya. Pada Teluk Ambon bagian dalam, dimana kondisi dasar perairan yang relatif dangkal berada pada kedalaman antara $0 \mathrm{~m}$ sd $40 \mathrm{~m}$ dengan jarak interval yang relatif berjauhan pada tiap kedalaman. Berdasarkan penelitian sebelumnya oleh Noya et al. (2016) ambang TAD memiliki lebar $<900 \mathrm{~m}$ dan kedalaman $<15 \mathrm{~m}$, sedangkan TAL kedalaman maksimum mencapai $145 \mathrm{~m}$. 


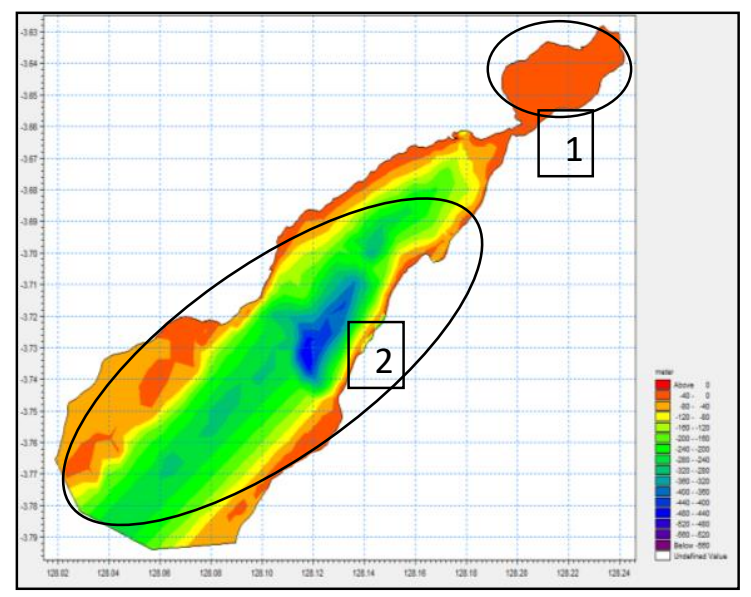

Gambar 5. Hasil pengukuran batimetri Teluk Ambon

Data kecepatan dan arah angin yang digunakan dalam penelitian ini adalah data selama 10 tahun (2006 s/d 2015) yang diperoleh dari stasiun BMKG Bandara Pattimura Ambon. Hasil pengolahan data selama 10 tahun terlihat bahwa kecepatan rata-rata angin sebesar $4,18 \mathrm{~m} / \mathrm{s}$ dan arah

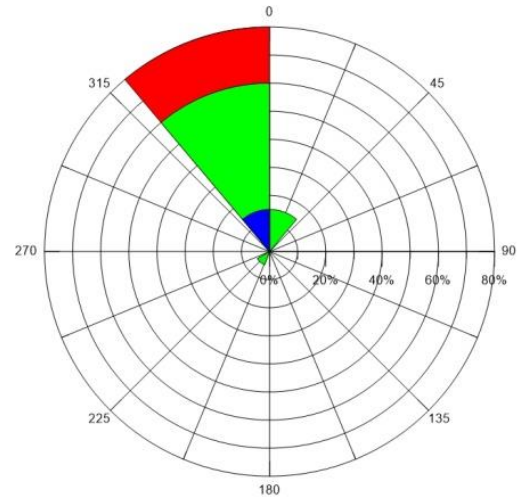

a angin dominan bergerak dari arah Selatan menuju ke Utara dengan arah rata-rata angin $296,50^{\circ}$. Pada gambar 6.a. sampai dengan gambar 6.b. terdapat wind rose untuk 4 musim yang berbeda dari tahun 2006-2015 untuk kecepatan rata-rata yang terjadi di Teluk Ambon.

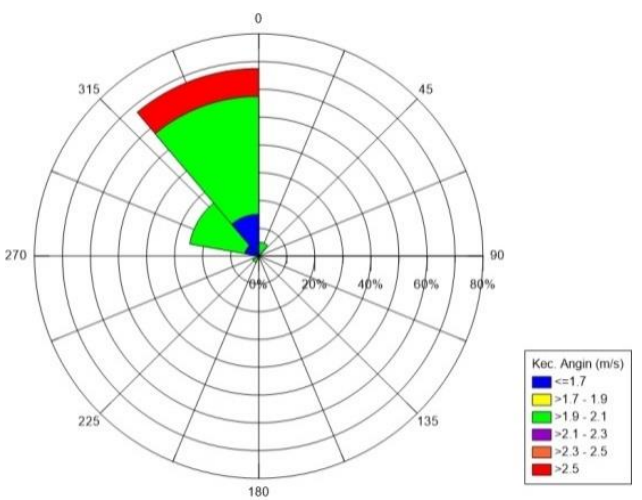

b

Gambar 6. a) Wind Rose rata-rata Musim Barat tahun 2006-2015, b) Wind Rose rata-rata Musim Peralihan I tahun 2006-2015

Pada Musim Barat (Desember-Januari) terlihat arah angin dominan menuju ke arah Barat laut dengan kecepatan berkisar antara $1,54 \mathrm{~m} / \mathrm{s}-2,57 \mathrm{~m} / \mathrm{s}$, sedangkan pada Musim Peralihan I (Februari-Mei) terlihat arah angin dominan juga menuju ke arah Barat laut dengan kecepatan berkisar antara $1,54 \mathrm{~m} / \mathrm{s}$ $2,57 \mathrm{~m} / \mathrm{s}$. Arah angin masih dominan ke arah Barat Laut karena masih dalam tahap peralihan dari musim sebelumnya dan kecepatan angin rata-rata juga tidak banyak mengalami perubahan dibandingkan kecepatan di Musim Barat. Dominasi arah angin dipengaruhi oleh adanya perbedaan tekanan antara 2 benua, yang mebangkitkan osilasi meridional sehingga mempengaruhi dominasi arah angin dan kecepatannya dimana arah angin akan condong mendekati osilasi utara dan selatan, menurut Okamoto et al. (2003) osilasi tahunan di perairan timur Indonesia disebabkan oleh pergerakan angin utara-selatan dari sirkulasi meridional (Hardley type). 


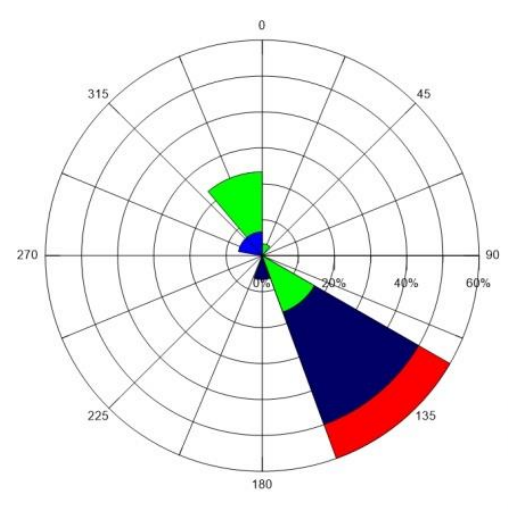

a

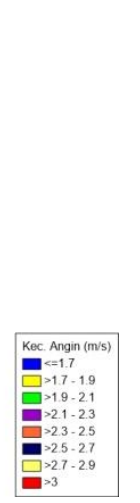

Gambar 7. a) Wind Rose rata-rata Musim Timur tahun 2006-2015, b) Wind Rose rata-rata Musim Peralihan II tahun 2006-2015

Arah angin dominan ke arah Tenggara dengan kecepatan berkisar antara $1,54 \mathrm{~m} / \mathrm{s}-$ $3,08 \mathrm{~m} / \mathrm{s}$ pada Musim Timur (Juni-Agustus). Terlihat juga sebagian arah angin ke arah Barat Laut dengan kecepatan berkisar 1,9 $\mathrm{m} / \mathrm{s}-2,1 \mathrm{~m} / \mathrm{s}$.Angin lebih dominan berhembus ke arah Barat Laut dengan kecepatan berkisar $1,54 \mathrm{~m} / \mathrm{s}-2,57 \mathrm{~m} / \mathrm{s}$ pada Musim Peralihan II (September-November). Arah angin pada musim ini akan condong mendekati arah Barat laut karena topografi Teluk Ambon yang sebagian besar dataran tinggi dan adanya peralihan ke Musim Barat. Faktor yang mempengaruhi karakteristik gelombang yang dibangkitkan oleh angin adalah lama angin bertiup, kecepatan angin dan fetch (jarak yang ditempuh angin dalam bergerak pada daerah pembangkitan gelombang). Daerah yang dipengaruhi oleh angin dan dibatasi oleh daratan yang

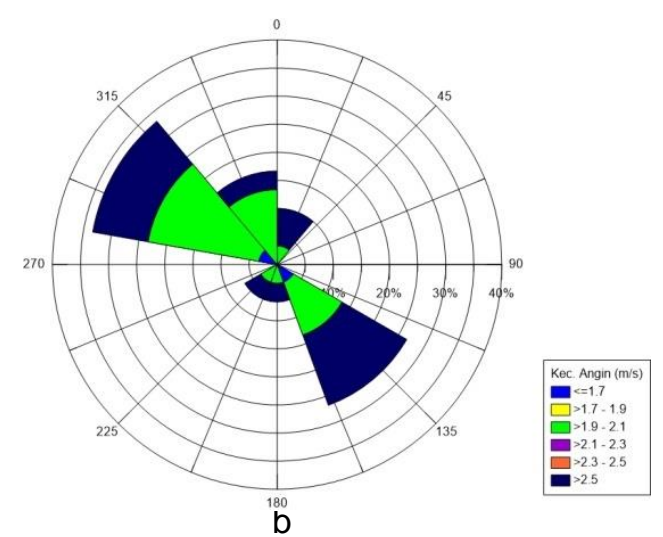

mengelilingi lautan serta memiliki arah yang konstan.

Dalam perhitungan pembangkitan gelombang di laut, fetch dibatasi oleh bentuk daratan yang mengililingi laut (Gambar 8). Pada daerah pembentukan gelombang, pembangkit gelombang tidak hanya dibangkitkan dalam arah yang sama dengan gelombang angin tetapi juga besarnya sudut terhadap arah angin. Menggunakan gambar 7, fetch efektif dihitung dengan menggunakan persamaan

$$
f_{e f f}=\frac{\sum X_{i} \cos \alpha}{\sum \cos \alpha}
$$

Pengukuran dilakukan mulai dari awal titik pembangkitan gelombang dengan interval sudut sebesar $6^{0}$.

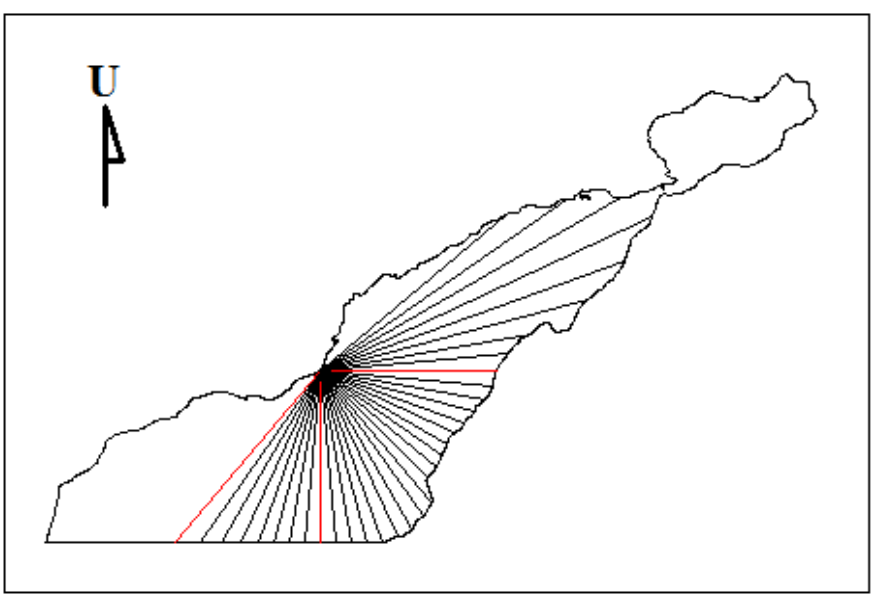

Gambar 8. Peta fetch di Teluk Ambon 
Tabel 1. Perhitungan fetch efektif Teluk Ambon

\begin{tabular}{llc}
\hline No & Arah Mata Angin & $F_{\text {eff }}(\mathrm{m})$ \\
\hline 1 & Utara & - \\
2 & Timur Laut & 4439,95 \\
3 & Timur & 5231,60 \\
4 & Tenggara & 6492,84 \\
5 & Selatan & 5655,52 \\
6 & Barat Daya & - \\
7 & Barat & 3597,21 \\
8 & Barat Laut & - \\
\hline
\end{tabular}

Menurut Soehedy (2011), didalam tinjauan pembangkitan gelombang di laut, fetch dibatasi oleh bentuk daratan yang mengelililngi laut. Jika data untuk menghitung fetch terbatas (di laut lepas), maka panjang fetch di laut lepas adalah $200 \mathrm{~km}$. Hubungan antara angin di atas laut dan angin di daratan diberikan oleh persamaan $R_{L}=U_{w} / U_{L}$. Untuk tegangan angin dihitung dengan menggunakan persamaan $U_{A}=0,71 U^{1,23}$. Setelah mengetahui nilai panjang fetch, faktor tegangan angin $\left(U_{A}\right)$ dan durasi angin maka tinggi dan periode gelombang signifikan dapat ditentukan. Hasil perhitungan menunjukkan bahwa nilai tinggi gelombang signifikan $(\mathrm{Hs})$ di Teluk Ambon sebesar 0,141 meter dengan periode signifikan (Ts) sebesar 1,401 detik. Hasil perhitungan koefisien refraksi $\left(\mathrm{K}_{\mathrm{r}}\right)$ pada tabel 2 menunjukkan bahwa refraksi terjadi karena adanya pengaruh perubahan kedalaman laut. $\mathrm{Di}$ daerah kedalaman perairan lebih besar dari setengah panjang gelombang, yaitu di laut dalam, gelombang menjalar tanpa dipengaruhi dasar laut. Di daerah ini, bagian dari puncak gelombang yang berada di air lebih dangkal akan menjalar dengan kecepatan yang lebih kecil daripada bagian air yang lebih dalam. Sehingga garis puncak gelombang akan membelok dan berusaha untuk sejajar dengan garis kedalaman laut. Selama gelombang menjalar dari laut dalam ke laut dangkal, gelombang akan mengalami deformasi gelombang. Perubahan bentuk tersebut disebabkan oleh proses refraksi, shoaling, difraksi dan refleksi (Triatmodjo, 2011).Dalam perhitungan koefisien refraksi dan koefisien shoaling, ditentukan 5 kedalaman yang berbeda. Koefisien tersebut kemudian akan digunakan untuk menentukan tinggi gelombang pecah, kecepatan gelombang, daya gelombang dan energi total gelombang.

Tabel 2. Nilai koefisien refraksi dan koefisien shoaling

\begin{tabular}{llccccc}
\hline No & $\begin{array}{c}\text { Kedalaman } \\
(\text { meter })\end{array}$ & 20 & 10 & 5 & 1 & 0,1 \\
\hline 1 & $\begin{array}{l}\text { Koefisien } \\
\text { Refraksi }\left(K_{R}\right)\end{array}$ & 0,95 & 1,08 & 1,31 & 0,98 & 0,85 \\
\hline 2 & $\begin{array}{l}\text { Koefisien } \\
\text { Shoaling }\left(K_{s}\right)\end{array}$ & 0,018 & 0,020 & 0,025 & 0,018 & 0,016 \\
\hline 3 & $\begin{array}{l}\text { Kecepatan Grup } \\
\text { Gel }\left(\mathrm{C}_{g}\right)\end{array}$ & 1,09 & 1,10 & 1,12 & 1,21 & 1,55 \\
\hline 4 & $\begin{array}{l}\text { Daya } \\
\text { Gelombang }\end{array}$ & 27,47 & 27,56 & 28,22 & 30,46 & 38,96 \\
\hline 5 & Energi Total Gelombang & \multicolumn{4}{c}{25,14} \\
\hline
\end{tabular}

Pemodelan simulasi gelombang signifikan yang terjadi di Teluk Ambon dilakukan pada empat musim yang berbeda. Keempat musim tersebut adalah Musim Barat (Desember-
Januari), Musim Peralihan I (Februari-Mei), Musim Timur (Juni-Agustus) dan Musim Peralihan II (September-November) di tahun 2015. 

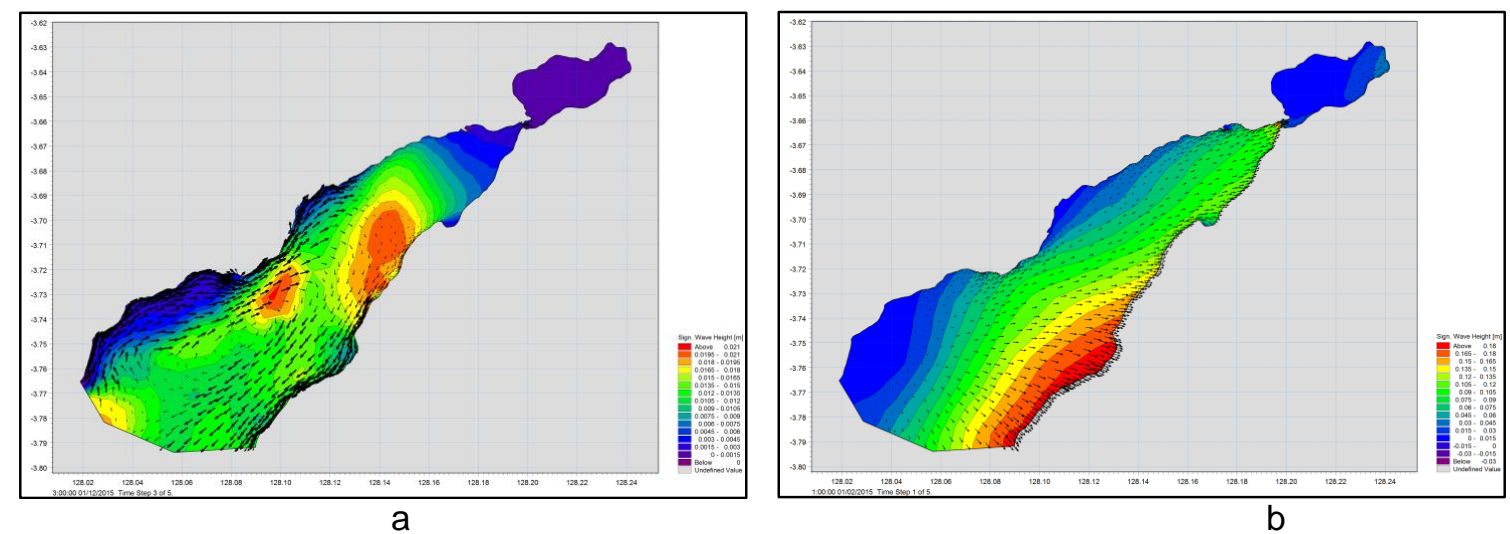

Gambar 9. a) Gelombang signifikan Teluk Ambon pada Musim Barat, b) Gelombang signifikan Teluk Ambon pada Musim Peralihan I

Gelombang pada Musim Barat (gambar 9.a) masuk ke dalam Teluk Ambon dari arah Utara dan kemudian di pertengahan Teluk Ambon memutar ke arah selatan menuju keluar mulut teluk. Perputaran arah gelombang ini disebabkan karena perubahan kontur kedalaman, arah angin dan vektor kecepatan gelombang yang mempengaruhi energi dan arah gelombang. Tinggi gelombang signifikan di Teluk Ambon relatif kecil berkisar 0-2,79 cm.Pada Musim Peralihan I (gambar 9.b) terlihat pada daerah mulut teluk, gelombang dominan bergerak ke arah Timur dan Tenggara. Semakin ke arah dalam teluk, gelombang lebih condong untuk bergerak ke arah Timur Laut. Perubahan arah gerak gelombang ini terjadi dominan karena pengaruh angin yg berhembus, kontur kedalaman serta bentuk topografi teluk. Tinggi gelombang signifikan paling besar terjadi di bagian Timur mulut teluk dengan ketinggian gelombang signifikan di seluruh bagian Teluk Ambon berkisar $0-21,7 \mathrm{~cm}$.

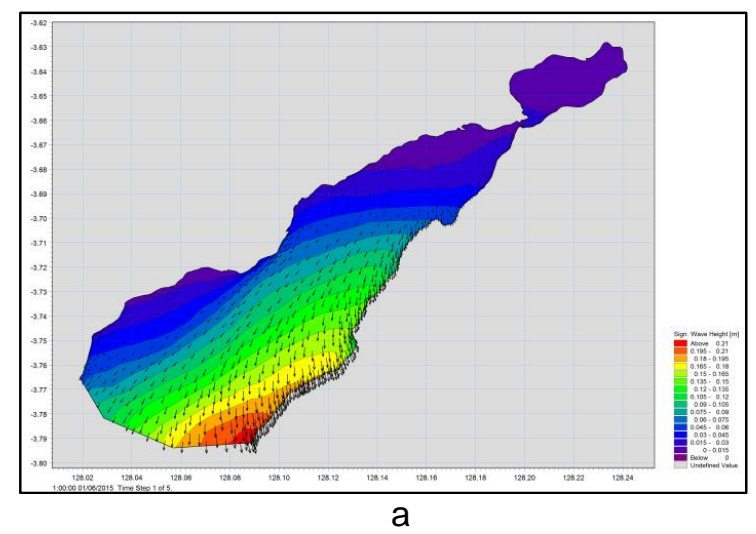

Arah gelombang pada Musim Timur (gambar 10.a) dominan bergerak ke arah mulut teluk dengan ketinggian gelombang signifikan berkisar $0-21,5 \mathrm{~cm}$. Tinggi gelombang paling besar dominan terjadi di bagian selatan mulut teluk. Hal ini sesuai dikarenakan arah angin yang bergerak dari Utara ke Selatan dan menuju ke arah laut lepas sehingga terjadi pembangkitan gelombang.Arah gelombang pada Musim Peralihan II (gambar 10.b) dominan bergerak ke arah mulut teluk dengan ketinggian gelombang signifikan berkisar $0-46,1 \mathrm{~cm}$. Tinggi gelombang paling besar dominan terjadi di bagian Selatan mulut teluk. Hal ini sesuai dikarenakan arah angin yang bergerak dari Utara ke Selatan dan menuju ke arah laut lepas sehingga terjadi pembangkitan gelombang. Arah gelombang pada musim ini tidak jauh berbeda dengan musim sebelumnya dikarenakan karakteristik cuaca yang hampir sama dan dalam rentang waktu peralihan musim.

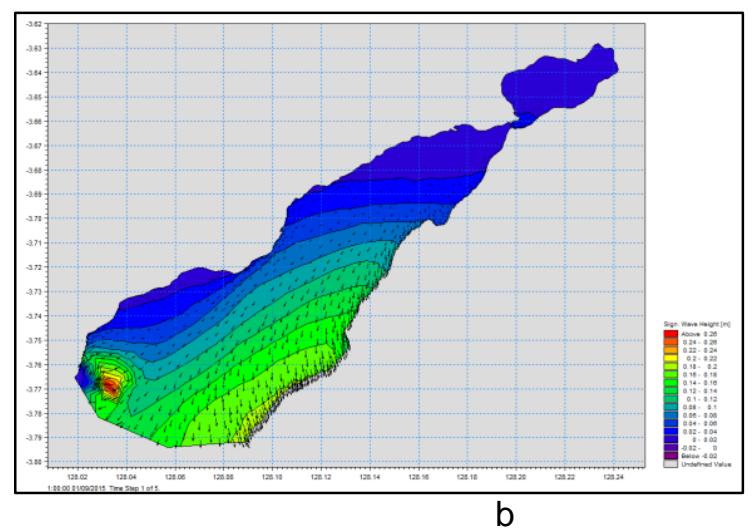

Gambar 10. a) Gelombang signifikan Teluk Ambon pada Musim Timur, b) Gelombang signifikan Teluk Ambon pada Musim Peralihan II 
Kedalaman perairan di titik situs kapal tersebut sedalam 27 meter. Arus yang akan dianalisa adalah arus mulai dari dasar perairan hingga permukaan dengan interval
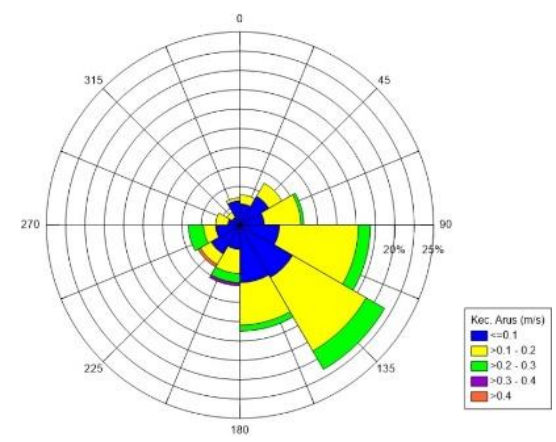

Gambar 11. a) Current rose permukaan, b) Current rose kedalaman 8,5 m
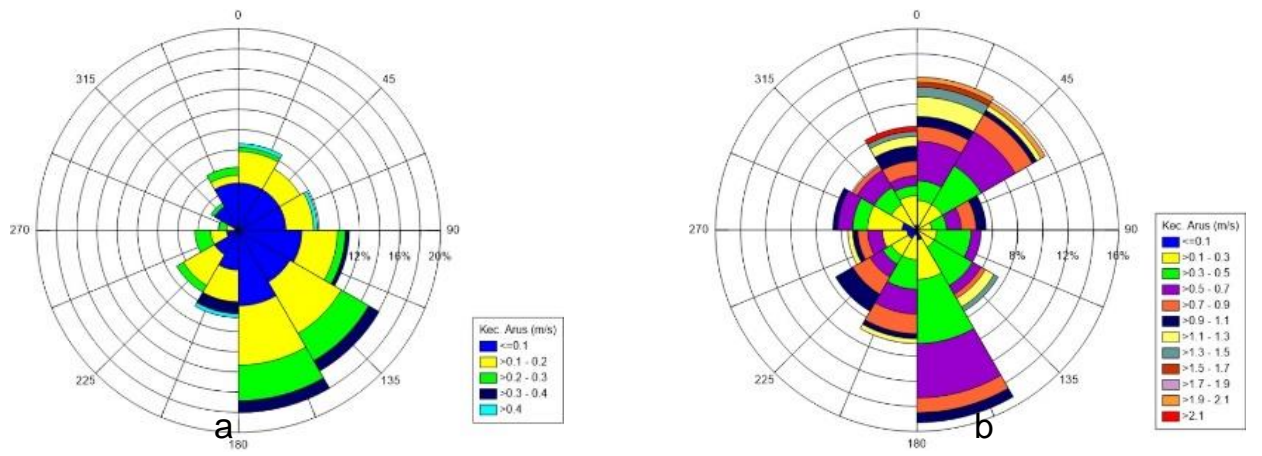

Gambar 12. a) Current rose kedalaman 20,5 m, b) Current rose kedalaman 26,5 m
Current rose yang terbentuk dari pengolahan data arus laut menggambarkan arah dominan arus laut. Hasil pada current rose menunjukan bahwa arah dominan arus ke Tenggara pada permukaan, kedalaman $3 \mathrm{~m}$, 8,5 m, 20,5 m, 23,5 m dan 26,5 m. Sedangkan pada current rose juga menggambarkan bahwa dominasi arus bergerak ke Tenggara dan Barat Laut pada kedalaman 5,5 meter. Perbedaan pola arus permukaan dengan arus vertikal dipengaruhi oleh faktor internal dan faktor eksternal. Penelitian yang dilakukan oleh Fadli dan Radjawane (2014) menyatakan bahwa pergerakan arus permukaan laut mengikuti arah pergerakan angin. Kecepatan arus pada lokasi penelitian antara 0.009-1.463 m/s.

Menurut Hoekstra et al. (2012) dalam Wisha et al. (2015) arus dipermukaan dipengaruhi oleh angin muson. Bulan Maret merupakan musim peralihan I, peralihan musim hujan kemusim kemarau dan angin berhembus dari Australia ke Asia. Teori ini sesuai dengan setiap kedalaman 3 meter. Pengukuran arus dari tanggal 18 April 2016 pukul 16.00 WIT sampai 20 April 2016 pukul 10.30 WIT setiap kedalaman dengan range tiap 3 meter.

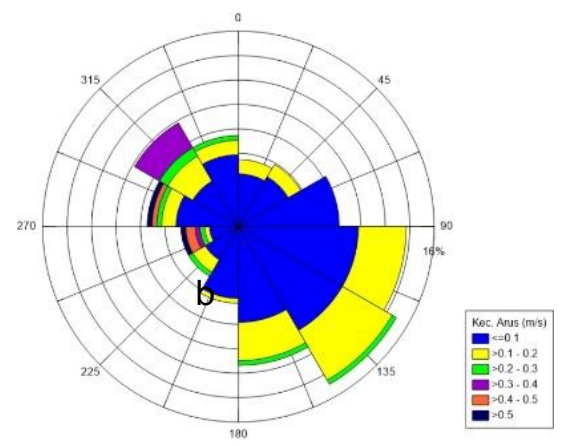

hasil current rose bahwa arah arus permukaan menunjukan pola yang hampir searah dengan angin (Gambar 11 dan 12).

Salah satu potensi wisata bawah air yang terdapat di perairan Teluk Ambon terdapat situs kapal kargo Duke of Sparta (SS.Aquila) yang diluncurkan pada tahun 1940 dari galangan kapal William Gray, West Hartlepool, dijual pada tahun 1951 untuk sebuah perusahaan Italia dari Napoli dan berganti nama SS Aquila sebelum tenggelam pada tahun 1958 di bagian Utara Perairan Teluk Ambon saat pemberontakan Permesta. Kapal tersebut di bom oleh pesawat Douglash B26 Invader yang merupakan bagian dari rencana CIA untuk mengacaukan perdagangan di Indonesia dengan menargetkan kapal dagang asing untuk melemahkan perekonomian Indonesia pada saat pemerintahan Ir.Soekarno (Wikipedia, 2016). Wreck Duke of Sparta (SS. Aquila) sangat dikenal oleh para penyelam lokal maupun mancanegara. situs kapal 
tenggelam tersebut berada di koordinat $122.172^{\circ} \mathrm{S}$ dan-3.665 $\mathrm{E}$. Kegiatan

penyelaman situs sesuai matrik penyelaman dengan level tertentu.

Tabel 3. Matrik Penyelaman

\begin{tabular}{|c|c|c|c|c|c|c|c|c|c|c|c|c|c|c|c|c|c|}
\hline & \multicolumn{4}{|c|}{ Rendah $(0-0,5 \mathrm{~m})$} & \multicolumn{4}{|c|}{ Sedang $(0,5-1 \mathrm{~m})$} & \multicolumn{5}{|c|}{ Tinggi $(1-1,5 \mathrm{~m})$} & \multicolumn{4}{|c|}{ Sangat tinggi $(>1,5 \mathrm{~m})$} \\
\hline $\begin{array}{l}\text { Gelombang } \\
\text { (Shore entry) }\end{array}$ & 1 & & & + & 2 & & & + & - & 3 & & & + & 4 & & & + \\
\hline \multirow{3}{*}{ Arus } & \multicolumn{4}{|c|}{ Longshore } & \multicolumn{4}{|c|}{ Down current $/$ Up current } & \multicolumn{5}{|c|}{ Rip current } & \multicolumn{4}{|c|}{ Surge } \\
\hline & Lemah & Sedang & Kuat & $\begin{array}{c}\text { Sangat } \\
\text { kuat }\end{array}$ & Lemah & Sedang & Kuat & $\begin{array}{c}\text { Sangat } \\
\text { kuat }\end{array}$ & \multicolumn{2}{|c|}{ Lemah } & Sedang & Kuat & $\begin{array}{c}\text { Sangat } \\
\text { kuat }\end{array}$ & Lemah & Sedang & Kuat & $\begin{array}{c}\text { Sangat } \\
\text { kuat }\end{array}$ \\
\hline & 1 & 2 & 3 & 4 & 3 & -4 & 4 & $4+$ & 2 & 2 & 3 & 4 & $4+$ & 2 & 3 & 4 & $4+$ \\
\hline Kedalaman objek & 1 & & & + & 2 & & & + & - & 3 & & & + & 4 & & & \\
\hline \multirow{2}{*}{ Visibility } & \multicolumn{4}{|c|}{$>15$} & \multicolumn{4}{|c|}{$14-5$} & \multicolumn{5}{|c|}{$4-2$} & \multicolumn{4}{|c|}{$<2$} \\
\hline & 1 & & & + & 2 & & & + & - & 3 & & & + & 4 & & & \\
\hline $\begin{array}{c}\text { Overhead } \\
\text { environment }\end{array}$ & \multicolumn{4}{|c|}{ none } & \multicolumn{4}{|c|}{ up to $12 \mathrm{~m}$ with light zone } & \multicolumn{5}{|c|}{12 up to $30 \mathrm{~m}$ with light zone } & \multicolumn{4}{|c|}{$>30 \mathrm{~m} / \mathrm{no}$ light zone } \\
\hline
\end{tabular}

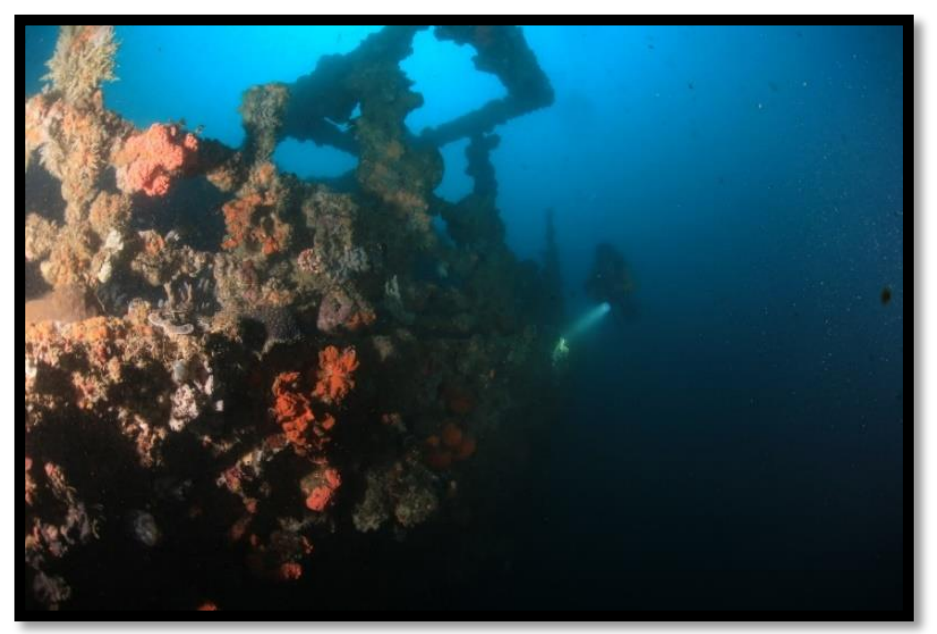

Gambar 13. Wisata Selam Wreck SS.Aquila,Wayame, Teluk Ambon (Sumber: Survei Lapangan, 2016)

\section{KESIMPULAN DAN SARAN}

Dari hasil pembahasan di atas didapatkan tipe pasut di perairan Teluk Ambon adalah pasut campuran condong harian ganda dengankedalaman perairan Teluk Ambon Dalam 0-40 m sedangkan pada Teluk Ambon Luar kedalaman berkisar 0 - 500 mserta keadaan dasar laut yang curam. Gelombang pada Musim Baratmasuk ke dalam Teluk Ambon dari arah Utara dan kemudian di pertengahan Teluk Ambon memutar ke arah selatan menuju keluar mulut teluk dengan tinggi gelombang signifikan di Teluk Ambon relatif kecil berkisar $0-2,79 \mathrm{~cm}$. Pada Musim Peralihan I terlihat pada daerah mulut teluk, gelombang dominan bergerak ke arah Timur dan Tenggara. Semakin ke arah dalam teluk, gelombang lebih condong untuk bergerak ke arah Timur Laut dengan ketinggian gelombang signifikan di seluruh bagian Teluk Ambon berkisar $0-21,7 \mathrm{~cm}$. Arah gelombang pada Musim Timur dominan bergerak ke arah mulut teluk dengan ketinggian gelombang signifikan berkisar $0-21,5 \mathrm{~cm}$. Tinggi gelombang paling besar dominan terjadi di bagian selatan mulut teluk.Arah gelombang pada Musim Peralihan II dominan bergerak ke arah mulut teluk dengan ketinggian gelombang signifikan berkisar 0-46,1 cm. 
Tinggi gelombang paling besar dominan terjadi di bagian Selatan mulut teluk.

Dasar laut teluk Ambon terdapat beberapa situs, salah satunya adalah SS.Aquila yang terletak di teluk Ambon Luar pada posisi $128.171495^{\circ} ;-3.665900^{\circ}$ dengan kedalaman $15 \mathrm{~m}-40 \mathrm{~m}$. Kecepatan arus di sekitar situs tersebut berkisar 0.0009-1.463 m/s. Berdasarkan hasil pembahasan hidrodinamika tersebut dapat disimpulkan bahwa kondisi perairan Teluk Ambon berdasarkan Indonesia Dive Directory layak dijadikan sebagai tempat wisata minat khusus dengan kriteria arus yang lemah dengan ketinggian gelombang rendah dan termasuk kategori penyelamanuntuk level 1 , 2, 3.

\section{UCAPAN TERIMA KASIH}

Ucapan Terimakasih kepada Loka Penelitian Sumber Daya dan Kerentanan Pesisir (LPSDKP) untuk DIPA anggaran 2016 penelitian APBN riset Teluk Ambon, Wisnu Arya Gemilang ST yang telah membantu dalam pembuatan peta dan semua pihak yang telah membantu dalam pelaksanaan penelitian ini.

\section{DAFTAR PUSTAKA}

Fadli, M., \& Radjawane, I. M. (2014). Pemodelan hidrodinamika di perairan teluk ambon hydrodynamic modelling in ambon bay. Prosiding PIT X ISOI 2013, 1(1).

Hiariey, J., \& Baskoro, M. S. (2011). Fishing Capacity of the Small-Pelagic Fishery at Banda Sea, Moluccas. Journal of Coastal Development, 14(2), 115-124.

Holthuijsen, L. H., Booij, N., \& Herbers, T. H. C. (1989). A prediction model for stationary, short-crested waves in shallow water with ambient currents. Coastal Engineering, 13(1), 23-54.

Kaihatu, M. M. (2013). Strategi pengembangan sektor perikanan dalam mendukung perekonomian wilayah kabupaten maluku tengah (Doctoral dissertation, Universitas Pattimura).

Komen, G. J., Cavaleri, L., Donelan, M., Hasselmann, K., Hasselmann, S., \& Janssen, P. A. E. M. (1996). Dynamics and modelling of ocean waves. Cambridge university press.

Latuconsina, H., Nessa, M. N., \& AmboRappe, R. (2012). Komposisi spesies dan struktur komunitas ikan padang lamun di perairan Tanjung TiramTeluk Ambon Dalam. Jurnal IImu dan Teknologi Kelautan Tropis, 4(1), 3646.

Noya, Y. A., Purba, M., Koropitan, A. F., \& Prartono, T. (2016). Cohesive Sediment Transport Modelling on Inner Ambon Bay. Jurnal IImu dan Teknologi Kelautan Tropis, 8(2), 671687.

Okamoto, N., Yamanaka, D. M., Ogino, S. Y., Hashiguchi, H., Nishi, N., Sribimawati, T., \& Numaguti, A. (2003). Seasonal variations of tropospheric wind over Indonesia: Comparison between collected operational rawinsonde data and NCEP reanalysis for 1992-99. Journal of the Meteorological Society of Japan. Ser. II, 81(4), 829-850.

Pattipeilohy, M. (2014). Fenomena pendangkalan zona pasang surut hutan mangrove teluk dalam ambon serta upaya pengembangan ekowisata. Jurnal Pena Sains, 1(2), 56-63.

Selanno, D. A. J., Tuahatu, J. W., Tuhumury, N. C., \& Hatulesila, G. I. (2014). Analysis of Lead $(\mathrm{Pb})$ content in the mangrove forest area in Waiheru District, Ambon. Aquatic Science and Technology, 3(1), 59-69.

Soehady, S. (2011). Analisis Kecepatan Angin Terhadap Panjang Pemecah Gelombang (Breakwater) pada Alur Pelabuhan Pulau Baai Bengkulu. Jurusan Teknik Sipil Universitas Bengkulu.

Suyadi, S. (2012). Satu Dekade Kondisi Hutan Mangrove di teluk Ambon, Maluku. Jurnal Biologi Indonesia, 8(1), 197-203.

Triadmodjo, B. (2011). Perencanaan Bangunan Pantai. Cetakan Pertama. Beta Offset Yogyakarta.

Wisha, U. J., Husrin, S., \& Prihantono, J. (2015). Hydrodynamics Banten Bay during Transitional Seasons (AugustSeptember). IImu kelautan: Indonesian Journal of Marine Sciences, 20(2), 101-112.

Young, I. R. (1999). Wind generated ocean waves (Vol. 2). Elsevier. 